\title{
Psychosocial assistance through a support group program as a strategy for handling adolescent social problems in the village of Merak Belantung, South Lampung
}

\author{
Muhammad Nurwahidin $^{1 *}$, Karomani ${ }^{2}$, Diah Utaminingsih ${ }^{3}$, Maulimin $^{4}$

\begin{abstract}
${ }_{1}^{1}$ Magister Teknologi Pendidikan, Universitas Lampung, Bandar Lampung, 35145, Lampung, Indonesia 2 Jurusan IImu Komunikasi, Lampung University, Bandar Lampung, 35145, Lampung, Indonesia Indonesia

${ }^{4}$ Program Studi Pendidikan Profesi Guru, University of Lampung, Bandar Lampung, 35145, Lampung, Indonesia
\end{abstract} \\ ${ }^{3}$ Program Studi Bimbingan Dan Konseling, University of Lampung, Bandar Lampung, 35145, Lampung,
}

\begin{abstract}
Abstrak. Tujuan dari kegiatan pengabdian kepada masyarakat ini adalah membantu meningkatkan kesadaran remaja tentang pentingnya sehat secara sosial serta membantu pemerintah Daerah Lampung Selatan mengurangi permasalahan-permasalahan sosial khususnya masalah sosial remaja. Masa remaja merupakan masa transisi dari masa anakanak ke masa dewasa. Dianggap dewasa belum, dianggap anak-anak juga bukan. Oleh karenanya remaja perlu didampingi secara psikososial supaya remaja bisa berkembang secara baik dan sesuai yang diharapkan oleh orang tua. Salah satu permasalahan remaja adalah masalah pencarian jati diri. Melihat situasai seperti ini timbul keiginan untuk mendampingi remaja dan bekerjasama dengan para tokoh masyarakat di Desa Merak Belantung Lampung Selatan untuk memberikan bimbingan dan penyuluhan serta pendampingan kepada para remaja warga di desa tersebut. Hal itu dilakukan supaya warga sadar akan pentingnya sehat secara sosial dan membantu pemerintah mengatasi masalah sosial remaja. Metode kegiatan untuk pengabdian kepada masyarakat ini menggunakan program Support Group, yang didalamnya akan ada kegiatan bimbingan, penyuluhan dan pendampingan psikososial kepada remaja di Desa Merak Belantung Lampung Selatan. Jika ini terealisir maka insyaalah permasalahan sosial remaja di Desa Merak Belantung Lampung Selatan akan teratasi. Salah satu kebanggaan kota Desa Merak Belantung adalah memiliki banyak tempat wisata yang ramai dikunjungi oleh para wisatawan baik lokal maupun domestik bahkan internasional. Keberadaan pariwisata tersebut idealnya memberi kontribusi kepada masyarakat khususnya remaja untuk berfikir dan bertindak sesuai normanorma sosial masyarakat Desa Merak Belantung Lampung Selatan. Kenyataannya para remaja malah terpengaruh dengan lingkungan wisata yang relatif bebas tersebut. Disinilah urgensi pengabdian kepada masyarakat ini dilakukan. Keberadaan tempat wisata seharusnya tidak mengurangi untuk menjadi remaja yang sholeh secara pribadi, sosial dan spiritual. Kesimpulan dari pengabdian ini adalah (1) Support group therapy yang diberikan membuat informan mengenali dirinya, memahami bahwa setiap orang memiliki kelebihan dan kekurangan dan juga sejarah masing-masing, serta bisa menerima dirinya; (2) Support
\end{abstract}

\section{* Corresponding author: mnurwahidin@yahoo.co.id}

Received 20 October 2021; Received in revised form 5 November 2021; Accepted 7 November Available online 29 December 2021

Lembaga Penelitian dan Pengabdian Kepada Masyarakat

Universitas Lampung 
group therapy yang telah dilaksanakan mampu memberikan fungsi terapeutiknya terhadap kelompok, yaitu sebagai faktor dukungan (supportive factors), faktor keterbukaan diri dan katarsis, faktor belajar kebijaksanaan atau kearifan dari anggota kelompok lainnya, serta faktor-faktor psikologis yang berkaitan dengan bagaimana menjalin hubungan dengan orang lain dan bagaimana memahami diri sendiri.

Kata kunci: pendampingan, psikososial, remaja

\section{Pendahuluan}

Desa Merak Belantung Lampung Selatan, merupakan salah satu daerah yang memiliki potensi wisata yang dapat meninngkatkan ekonomi masyarakat di desa tersebut. Namun pada kenyataannya, permasalahan sosial di daerah wisata justru lebih beragam dan banyak dilakukan oleh para remaja, permasalahan yang kadangkala terjadi di daerah tersebut adalah rendahnya etika perilaku para remaja, dan keinginan remaja untuk hidup bebas tanpa memperdulikan aturan lebih banyak. Permaslahan remaja ini dikarenakan remaja berada pada tahap pencarian jati diri. Menurut WHO (Sarwono, 2011) remaja adalah suatu masa dimana individu berkembang dari saat pertama kali ia menunjukan tanda-tanda seksual sekundernya sampai saat ia mencapai kematangan seksualnya, individu mengalami perkembangan psikologis dan pola identifikasi dari kanak-kanak menjadi dewasa dan terjadi peralihan dan ketergantungan sosial ekonomi yang penuh kepada keadaan yang relatif lebih mandiri [1]. Masa remaja merupakan masa transisi dari masa anak menuju masa dewasa yang ditandai dengan adanya perubahan-perubahan baik fisik maupun psikis. Idealnya remaja itu memiliki pola pikir positif, kreatif dan optimis. Remaja yang memiliki pola pikir positif pasti akan merasa yakin dalam setiap tindakannya. Walaupun hasilnya tidak memuaskan, setidaknya sudah berusaha dan mencoba memperbaikinya. Remaja yang memiliki pola pikir kreatif akan selalu membuat hal yang baru. Remaja yang berpola pikir optimis pasti akan melihat kesempatan didalam kesulitannya.

Manusia hidup sebagai makhluk sosial. Tidak ada yang bisa hidup sendirian tanpa ada bantuan orang lain. Perkembangan psikososial yang didefinisikan sebagai faktor-faktor yang berkaitan dengan lingkungan sosial atau interaksi dengan orang lain dapat memberikan pengaruh terhadap perilaku individu anak [2]. Hasil penelitian tentang psikososial anak jalanan Sakalasastra \& Herdiana (2012) menyimpulkan bahwa faktor psikososial pada anak jalanan korban pelecehan seksual dapat dijelaskan dalam empat dimensi yaitu dimensi afeksi, psikomotorik, kognisi dan social [3]. Adanya kecenderungan emosi negatif seperti perasaan benci dan menyimoan dendam, keinginan untuk hidup bebas, penilaian negatif pada diri sendiri dan kehidupan, perilaku seksual yang tidak wajar, pengobatan obat-obatan terlarang dan konsumsi alkohol, serta relasi yang buruk dengan keluarga atau lingkungan sekitarnya.

Situasi di tempat lokasi pengabdian masyarakat menunjukan bahwa sebenarnya di Desa Merak Belantung Lampung Selatan sudah terdapat beberapa tempat ibadah dan tempat bermain serta kegiatan olahraga sehingga secara teori bisa membentuk remaja menjadi orang yang tangguh dan kuat. Kenyataannya tidaklah demikian, beberapa remaja mengalami permasalahan psikososial seperti pemarah, kasar, suka memberontak, menuntut kebebasan berlebih, ingin tampak sama dengan sesama teman, bicara kurang sopan, dan sebagainya. Beberapa faktor yang mempengaruhi fenomena tersebut berdasarkan observasi pengabdi antara lain kurangnya kasih sayang orang tua, kurangnya pengawasan orang tua, pergaulan dengan teman yang tidak sebaya, pengaruh iptek yang 
berdampak negatif, iman yang lemah, tidak ada bimbingan dari orang tua dan tidak ada media penyalur bakat. Pemberdayaan remaja dengan cara pendampingan melalui program support group tersebut penting karena remaja merupakan calon generasi pemimpin masa depan Bangsa. Jika fenomena tersebut dibiarkan, maka akan terjadi dekadensi dan degradasi moral remaja yang berdampak pada generasi muda kita yang buruk. Alasan itulah yang membuat pengabdi ingin melakukan pengabdian masyarakat dengan tema pendampingan psikososial melalui program support group di Desa Merak Belantung Lampung Selatan.

Berdasarkan hasil diskusi dengan pihak terkait yaitu para tokoh masyarakat yang diwakili Bapak Joni Arizon, permasalahan utama pada remaja di Desa Merak Belantung Lampung Selatan adalah: kurangnya kasih sayang orang tua, kurangnya pengawasan orang tua, pergaulan dengan teman yang tidak sebaya, pengaruh iptek yang berdampak negatif, iman yang lemah, tidak ada bimbingan dari orang tua dan tidak ada media penyalur bakat. Permasalahan-permasalahan tersebut berkait dengan permasalahan sosial budaya dan agama. Kondisi lingkungan yang kurang baik mempengaruhi permasalahan di atas. Begitu juga dengan budaya dimana orang tua kurang perhatian dan pengawasan serta iman agama yang lemah membuat remaja mengalami berbagai masalah.

Sesuai dengan kegiatan yang telah direncanakan, maka tujuan pengabdian kepada masyarakat ini adalah:1.) Untuk melakukan pendampingan psikososial pada remaja, 2.) Berusaha secara maksimal untuk mengupayakan teralisasinya media penyaluran bakat dan minat, 3.) Untuk meningkatkan kualitas sumber daya manusia yang mampu mendidik remaja, 4.) Melakukan kerjasama mitra dengan RT dan RW supaya selalu punya perhatian lebih kepada remaja.

Sedangkan manfaat adanya kegiatan Pengabdian ini adalah: 1.) Secara teoritis akan menambah wawasan tentang teori psikososial, 2.) Secara praktis membentuk kepribadian remaja sebagai manusia yang berkarakter, memiliki perencanaan untuk mencapai masa depan lebih baik, berguna bagi keluarga dan masyarakat.

Dampak bagi masyarakat dengan adanya kegiatan pengabdian ini adalah: 1.) Membaiknya moral remaja, 2.) Terbinanya silaturahim antar masyarakat dengan insan perguruan tinggi, 3.) Melahirkan generasi-generasi yang baik, tangguh, berkarakter

\section{Tinjauan Pustaka}

Yang dimaksud pendampingan psikososial disini adalah paduan antara penanganan psikologis dan penanganan sosial. Perpaduan ini menyatukan penanganan psikologis yang bertumpu pada pemahaman interpersonal klien dengan persoalan sosial budaya yang melingkupi kehidupan klien. Pendampingan psikososial ini merupakan terapi atau cara dalam proses perawatan dan pemulihan subjek dari masalah psikososial yang dilakukan oleh ahlinya dengan menggunakan pendekatan psikologis, afeksi, dukungan moral dan spiritual serta pembinaan hubungan sosial dengan tujuan membantu individu menjalankan peran dan fungsinya dengan baik di tengah masyarakat.

\subsection{Indikator Keberhasilan Pendampingan Psikososial}

Menurut Suardiman (2011), indikator keberhasilan pendampingan psikososial bahwa klien yang didampingi dapat melakukan aktivitas sebagai berikut [4]: 
1. aktivitas berkumpul dan berkomunikasi. Kebutuhan ini untuk berhubungan dengan orang lain sebagai hakikat manusia sebagai makhluk sosial dengan melakukan kegiatan-kegiatan dan hobi klien untuk menghilangkan rasa kesepian dan tidak berguna yang muncul karena kurangnya aktivitas sehingga dapat memberikan dorongan hidup agar tidak mengalami Post Power Syndrome. Kondisi ini berbeda saat terjadinya bencana yang menyebabkan pergeseran psikologis yang berdampak pada kondisi remaja yang menjadi kurangnya semangat, motivasi dan tujuan hidup karena kehilangan yang dirasakan sehingga keinginan untuk berinteraksi dengan lingkungannya pun menjadi kurang.

2. mampu berkarya. Definisi berkarya dimaksud bukan hanya melakukan aktivitas ekonomi tetapi juga melakukan aktivitas domestik. Perbedaan dengan kondisi saat terjadinya bencana yang mengakibatkan terputusnya akses masyarakat dalam segala lini kehidupan seperti rusaknya lahan dan hilangnya aset penopang mata pencaharian yang membuat masyarakat tidak lagi mampu melakukan aktivitasnya secara normal.

3. mampu bersosialisasi yaitu seseorang mampu kembali melakukan aktivitas sosial yang ada di lingkungan sekitarnya sehingga dapat berinteraksi kembali dengan masyarakat yang ada dengan ikut berpartisipasi dalam kegiatan sosial yang ada seperti pengajian, arisan, PKK dan gotong royong. Hal ini berbeda dengan kondisi saat itu, bencana yang terjadi mengubah kehidupan sosial masyarakat yang berdampak pada lumpuhnya aktivitas sosial yang telah ada. Hal ini sangat berpengaruh pada putusnya bersosialisasi.

\subsection{Program Support Group}

Support Group merupakan salah satu metode dimana sekelompok orang dapat bertukar pikiran akan masalahnya dan mereka dapat bersama-sama mendiskusikan pengalaman mereka dengan menyumbangkan ide-ide atau gagasannya serta saling memberikan dukungan satu sama lain. Tujuan dari program Support Group ini adalah memberikan dukungan, yang dapat menghasilkan perubahan pada aspek emosi, kognitif, dan perilaku.

Program Support Group diharapkan dapat memberikan alternatif layanan konseling yang nantinya dapat dilakukan secara mandiri oleh kelompok yang akan diberikan perlakuan.

\subsection{Tahapan Pendampingan Psikososial}

Sedangkan Tahapan-tahapan pendampingan sosial menurut teorinya Max Siporin yang dikutip oleh (Huda, 2009) ada 5 tahapan dalam melakukan proses pekerja sosial yang saling berkaitan dan mempengaruhi yaitu [5]:

1. Assasment. merupakan proses pengumpulan dan mengolah informasi dari klien untuk mengetahui jenis permasalahan, penyebab permasalahan, tingkat kedalaman masalah, akibat permasalahan dan sebagainya. Assasment ini akan mempengaruhi intervensi yang akan dilakukan. Penggalian data dan informasi dapat diperoleh melalui observasi atau pengamatan, berinteraksi baik kepada klien sendiri maupun melalui keluarga dan masyarakat maupun tes psikologi.

2. Engagement, yaitu pembuatan perencanaan intervensi sesuai dengan permasalahan yang terjadi. Manfaat tahap ini untuk memecahkan masalah dimana sumber data 
dalam perencanaan ini adalah hasil assasment sehingga dibutuhkan analisis yang tajam sehingga intervensi yang direncanakan relevan dengan problem yang ada.

3. Intervention, yaitu proses melakukan tindakan pemecahan masalah yang telah direncanakan sebelumnya. Intervensi dalam hal ini melalui proses konseling dan terapi. Di dalam melakukan terapi bisa digunakan satu atau dua bahkan lebih strategi terapi dalam proses intervensi.

4. Termination ialah proses menghentikan intervensi apabila dianggap sudah selesai. Pemutusan kerja ini karena klien dianggap sudah Mandiri dan tidak memerlukan peran pendamping secara intensif. Pendamping mulai mengurangi waktu untuk berinteraksi dengan klien secara profesional hal ini ditujukan agar klien tidak bergantung kepada pendamping atau Pekerja Sosial.

5. Evaluation yaitu proses melakukan evaluasi terhadap proses pendampingan baik dari identifikasi masalah, perencanaan intervensi, intervensi hingga terminasi. Hal yang perlu diperbaiki dan dipertahankan dapat dimasukkan dalam proses evaluasi ini.

Psikologi sosial adalah psikologi dalam konteks sosial. Psikologi seperti yang kita ketahui adalah ilmu tentang perilaku. Sedangkan sosial disini berarti interaksi antar individu atau antar kelompok dalam masyarakat [1].

Masalah sosial adalah kondisi yang dialami seseorang yang disebabkan oleh terganggunya relasi sosial, sikap dan perilaku meliputi gangguan pemikiran, perasaan, perilaku dan atau relasi sosial yang secara terus menerus saling mempengaruhi satu sama lain.

Tujuan pendampingan sosial remaja adalah memperbaiki dan mengembangkan remaja dalam interaksi antar individu, kelompok dan masyarakat sehingga mereka dapat melaksanakan tugas kehidupannya dan dapat mengatasi permasalahan atau kesulitan yang dihadapi dan mencapai kesejahteraan dalam kehidupannya. Pendampingan remaja pada prinsipnya ditunjukkan untuk membantu dalam meningkatkan fungsionalitas sosial individu sebagai perorangan maupun sebagai kelompok sehingga dapat melaksanakan tugas-tugas kehidupannya dan melaksanakan fungsi sosialnya.

Tahap-tahap pendampingan sosial remaja sebagai berikut

1. membantu orang meningkatkan dan menggunakan kemampuannya secara efektif untuk melaksanakan tugas-tugas kehidupan dan memecahkan masalah klien

2. mengaitkan individu dengan sistem sumber

3. mempermudah interaksi, mengubah dan menciptakan relasi antara orang dan sistem sumber kemasyarakatan, maupun relasi antara orang dilingkungan sistem sumber

4. meratakan sumber-sumber material

5. bertindak sebagai pelaksana kontrol sosial

6. Oleh karenanya peran pendamping sosial remaja di situ adalah mendampingi klien pada setiap tindakan, memberikan dukungan dukungan emosional yang diperlukan dan berupaya membantu klien dalam mengatasi hambatan yang dihadapinya.

\section{Metode Pengabdian}

Untuk menyelesaikan permasalahan tersebut di atas, maka pendekatan penyelesaiannya adalah menggunakan Program Support Group, yang mana didalamnya akan dilakukan 
beberapa pendekatan antara lain:
a. Pendekatan personal
b. Pendekatan pendampingan
c. Pendekatan keagamaan
d. Pendekatan olahraga dan seni
e. Pendekatan penyaluran bakat dan minat

\subsection{Prosedur Kerja}

Untuk menyelesaikan permasalahan di atas maka perlu ditempuh prosedur kerja, yaitu:

1. Menemui tokoh masyarakat terutama Ketua RT dan RW dengan membawa Surat tugas Pengabdian Kepada Masyarakat

2. Meminta masukan mengenai kondisi real remaja secara umum dan khusus

3. Melakukan survey pendahuluan

4. Melakukan identifikasi masalah remaja

5. Analisis Masalah

6. Menyelesaikan masalah remaja (pendekatan personal, pendekatan pendampingan, pendekatan keagamaan, pendekatan olahraga dan seni, pendekatan penyaluran bakat dan minat)

7. Membuat Laporan Pengabdian kepada Masyarakat

\section{Hasil dan Pembahasan}

Secara keseluruhan perlakuan yang diberikan melalui support peer therapy memiliki efek yang signifikan. Hal ini dibuktikan dengan adanya perubahan perilaku melalui observasi dan juga hasil skor kuesioner yang diberikan sebelum perlakuan dan sesudah perlakuan. Hasil observasi perubahan perilaku yang terlihat secara umum muncul dalam tabel berikut ini:

Tabel 4.1. Hasil Observasi Perubahan Perilaku

\begin{tabular}{lll}
\hline \multicolumn{1}{c}{ Aspek } & \multicolumn{1}{c}{ Sebelum perlakuan } & \multicolumn{1}{c}{ Sesudah Perlakuan } \\
\hline Perhatian & Peserta cenderung tidak perduli & Peduli \\
Keaktifan berpartisipasi & Keaktifan berpartisipasi kurang & aktif berpartisipasi \\
Komunikasi & Komunikasi dingin & Komunikatif \\
Mengemukakan pendapat & Mengemukakan pendapat kurang & Aktif mengemukakan pendapat \\
& berani & \\
Memahami tujuan dan cita-cita & Tidak memahami tujuan dan cita-cita & Memahami tujuan dan cita-cita
\end{tabular}

Hasil analisis skor kuesioner juga membuktikan adanya perubahan yang signifikan, dimana total skor awal adalah 601 dan total skor setelah perlakuan adalah 1008. Hasil ini dapat ditunjukkan oleh gambar sebagai berikut: 


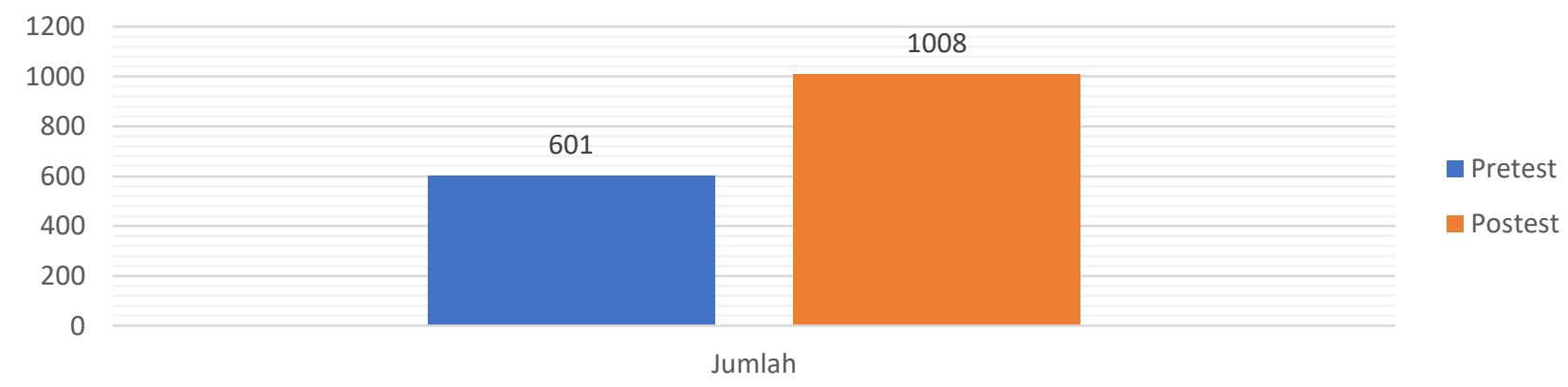

Gambar 1. Skor Awal dan Akhir

Dari hasil analisis terhadap kuesioner pre-tes dan post tes didapatkan data Per Subjek, dimana terlihat perbedaan skor awal dan skor setelah diberi perlakuan. Terlihat juga peningkatan pada masing-masing subjek sebagai berikut:

\subsection{Subjek 1}

\section{Total}

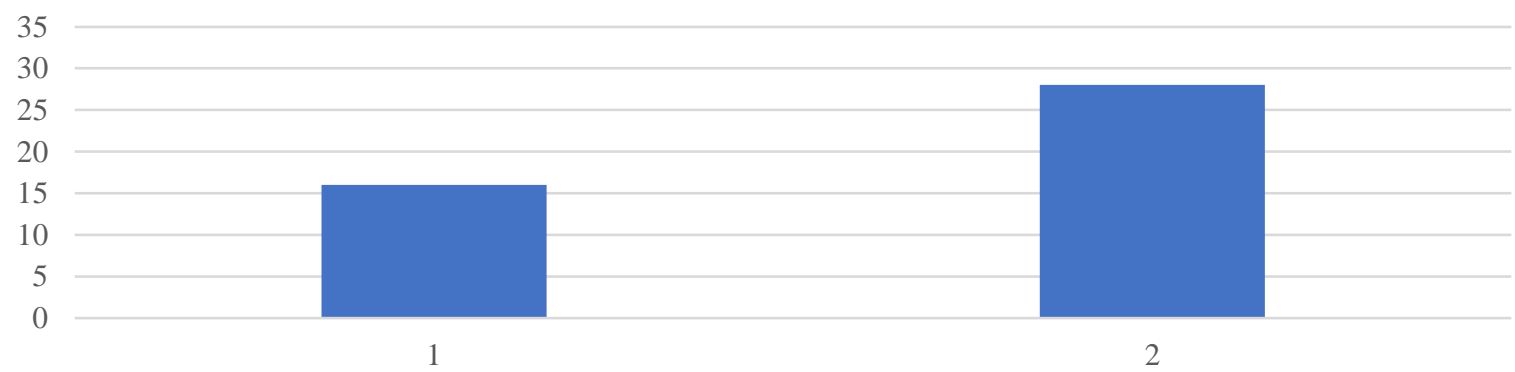

Gambar 2. Skor Awal dan Akhir Subjek 1

Pada subjek 1 dapat dilihat bahwa pada data pre-test total skor yang ia dapat adalah 16 dan pada post-test total skor yang ia dapat adalah sejumlah 28. Maka dapat disimpulkan bahwa pada subjek 1 terdapat peningkatan sebanyak $57 \%$.

\subsection{Subjek 2}

\section{Total}

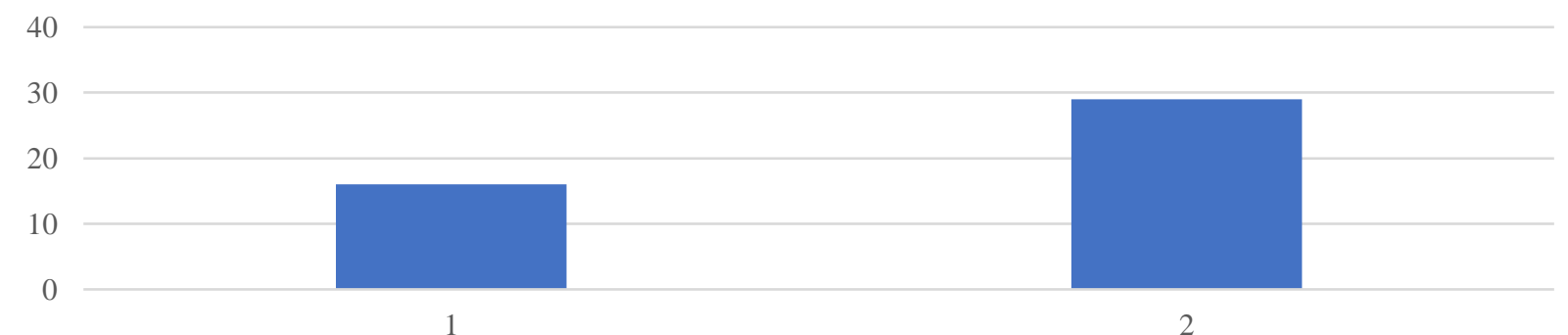

Gambar 3. Skor Awal dan Akhir Subjek 2

Untuk subjek 2 dapat dilihat bahwa pada saat pre-test ia mendapatkan total skor sebanyak 16 dan pada post-test mendapat total skor sebanyak 29. Dapat dikatakan bahwa subjek 2 mengalami peningkatan dari hasil pre-test dan post-test sebanyak 55\%.

\subsection{Subjek 3}




\section{Total}

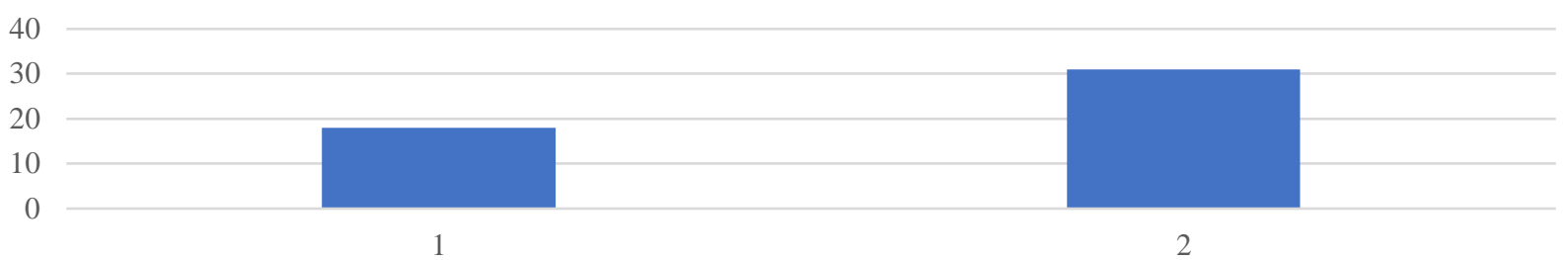

Gambar 4. Skor Awal dan Akhir Subjek 3

Pada data subjek 3 dapat dilihat bahwa pada pre-test subjek mendapatkan total skor sebanyak 18 skor dan untuk post-test subjek mendapat total skor sebanyak 31 skor. Maka dapat dikatakan bahwa ada peningkatan sebanyak $58 \%$ pada subjek 3 .

\subsection{Subjek 4}

\section{Total}

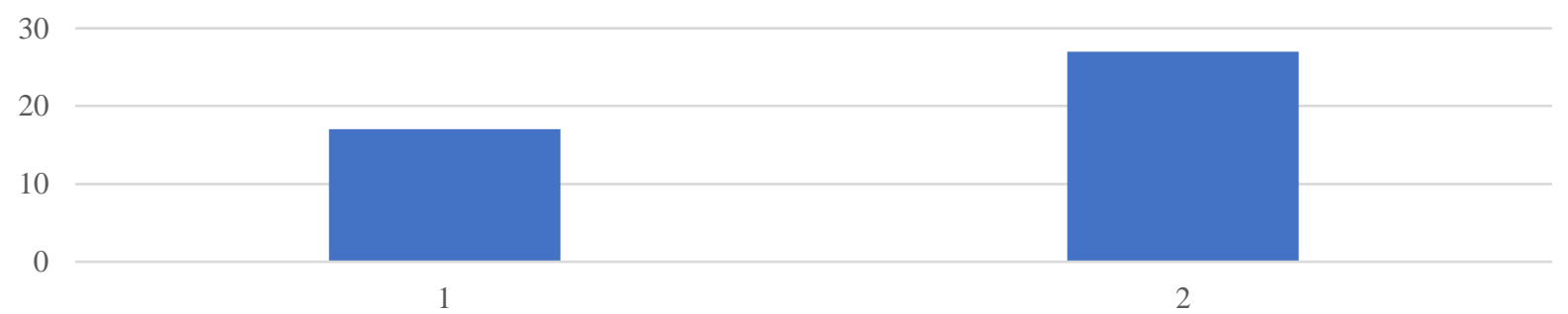

Gambar 5. Skor Awal dan Akhir Subjek 4

Pada data subjek 4 dapat dilihat bahwa pada total skor pre-test subjek mendapat skor 17 dan pada saat post-test subjek mendapat skor 27. Maka dapat dikatakan bahwa subjek 4 mengalami peningkatan sebanyak $62 \%$.

\subsection{Subjek 5}

\section{Total}

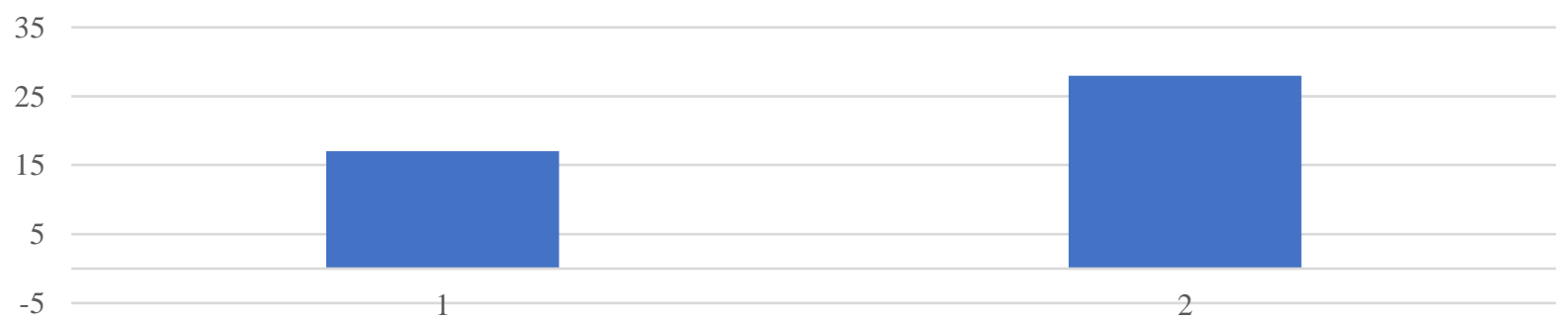

Gambar 6. Skor Awal dan Akhir Subjek 5

Pada hasil data analisis untuk subjek 5 dapat dilihat bahwa pada pre-test ia mendapatkan total skor sebanyak 17 dan pada saat post-test ia mendapatkan total skor sebanyak 28. Dari hasil tersebut dapat dikatakan bahwa subjek 5 mengalami peningkatan sebanyak $60 \%$ dari pre-test ke post-test. 


\subsection{Subjek 6}

\section{Total}

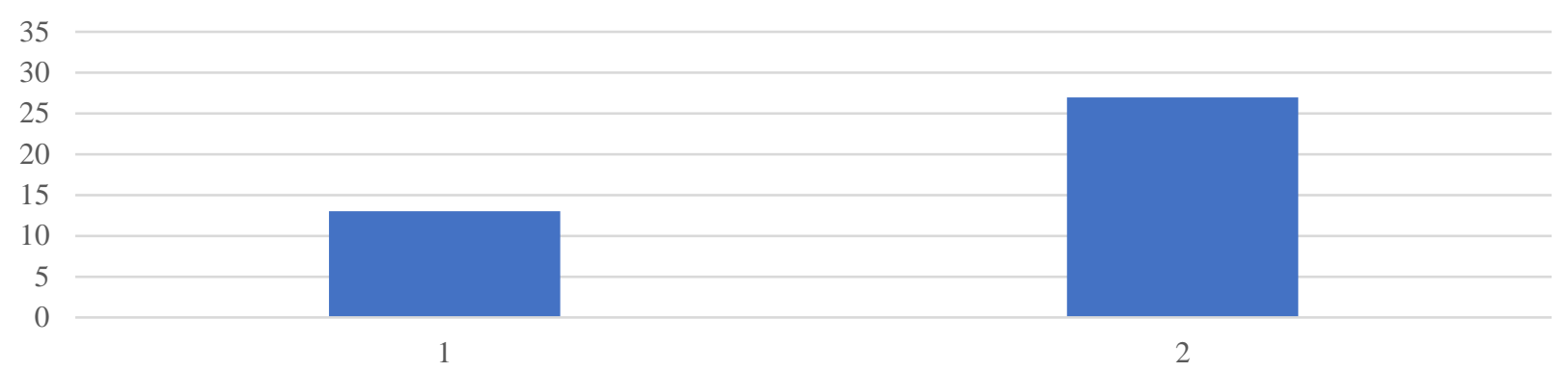

Gambar 7. Skor Awal dan Akhir Subjek 6

Pada total skor dari subjek 6, dapat dilihat bahwa pada saat pre-test ia mendapatkan total skor sebanyak 13 dan pada saat post-test subjek mendapat skor sebanyak 27 . Jadi, dapat dikatakan bahwa subjek 6 mengalami peningkatan sebanyak 48\% dari pre-test ke post-test.

\subsection{Subjek 7}

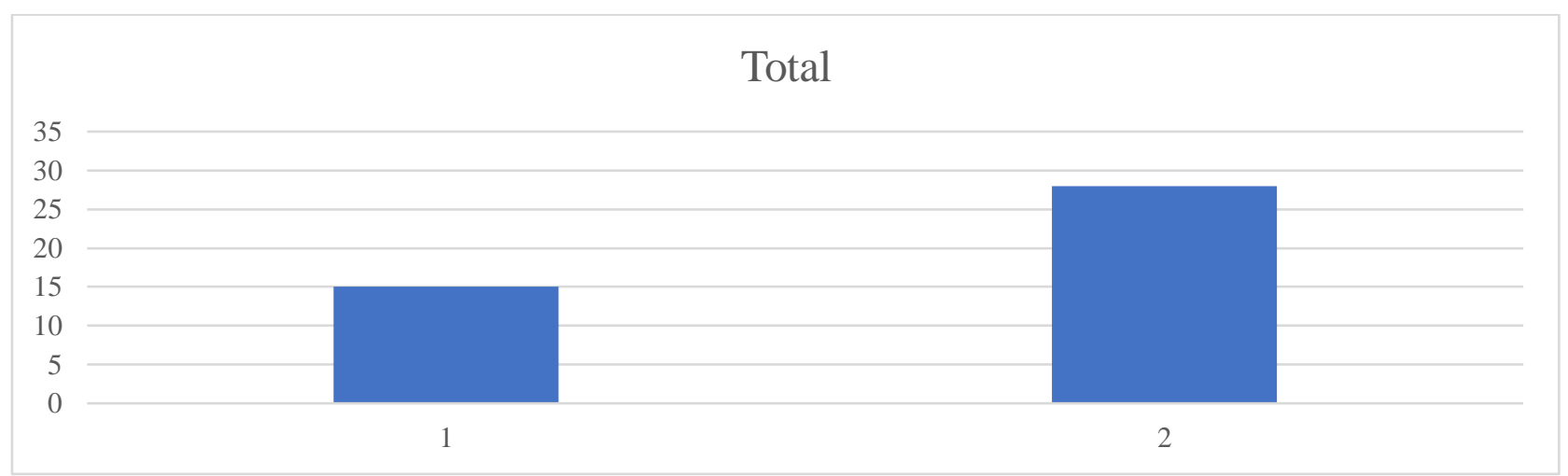

Gambar 8. Skor Awal dan Akhir Subjek 7

Pada data subjek 7 dapat dilihat bahwa subjek mendapat total skor sebanyak 15 pada pre-test dan pada post-test subjek mendapat total skor sebanyak 28. Dari pernyataan diatas, maka dapat dikatakan bahwa subjek mengalami peningkatan sebanyak 53\%.

\subsection{Subjek 8}

\section{Total}

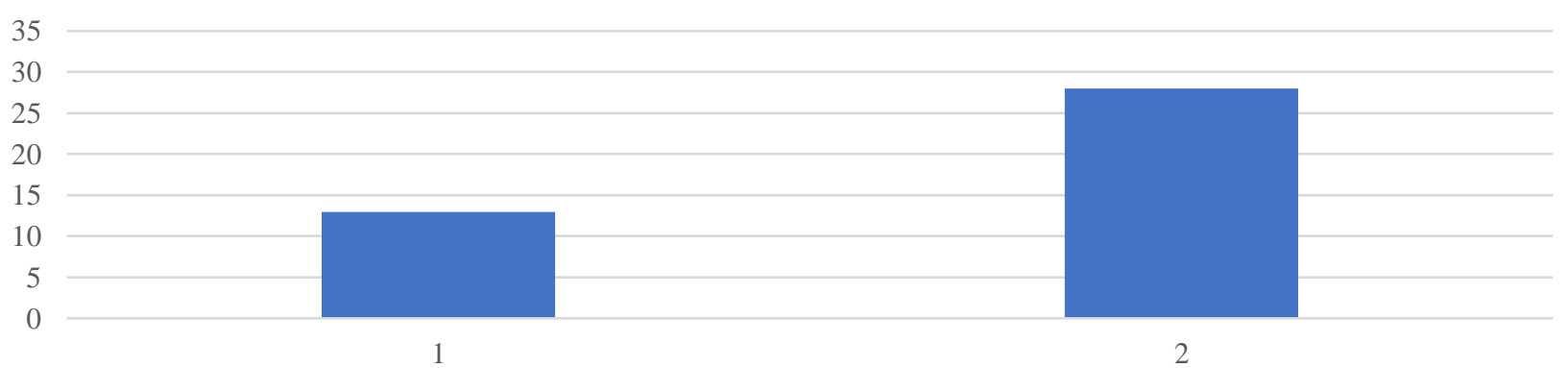

Gambar 9. Skor Awal dan Akhir Subjek 8

Pada subjek 8 , dapat dilihat bahwa subjek mendapat total skor pre-test sebanyak 13 , dan pada post-test subjek mendapat total skor sebanyak 28 . Sehingga dapat disimpulkan bahwa 
subjek 8 mengalami peningkatan sebanyak 46\% pada analisis ini.

\subsection{Subjek 9}

\section{Total}

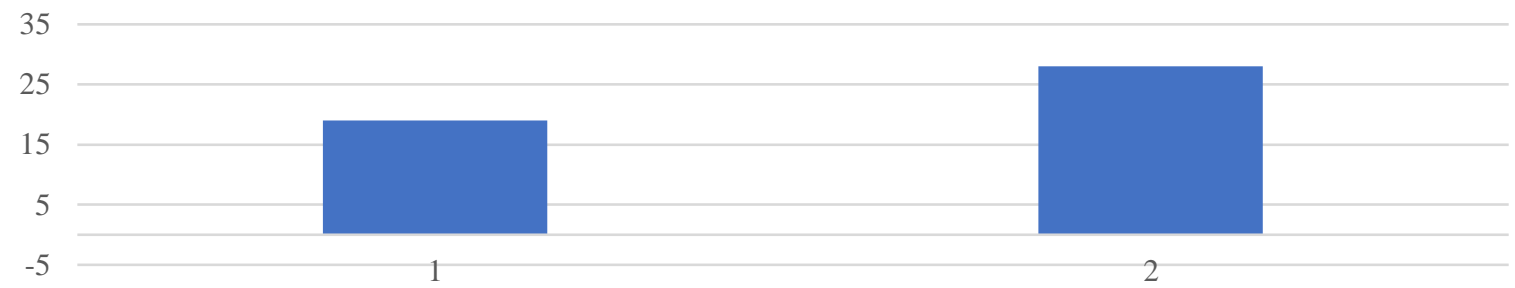

Gambar 10. Skor Awal dan Akhir Subjek 9

Pada subjek 9 dapat dilihat bahwa pada total skor pre-test ia mendapatkan skor sebanyak 19 dan pada saat post-test subjek mendapatkan skor sebanyak 28. Maka dapat dikatakan bahwa subjek 9 mengalami peningkatan sebanyak 67\% dari pre-test ke post-test.

\subsection{Subjek 10}

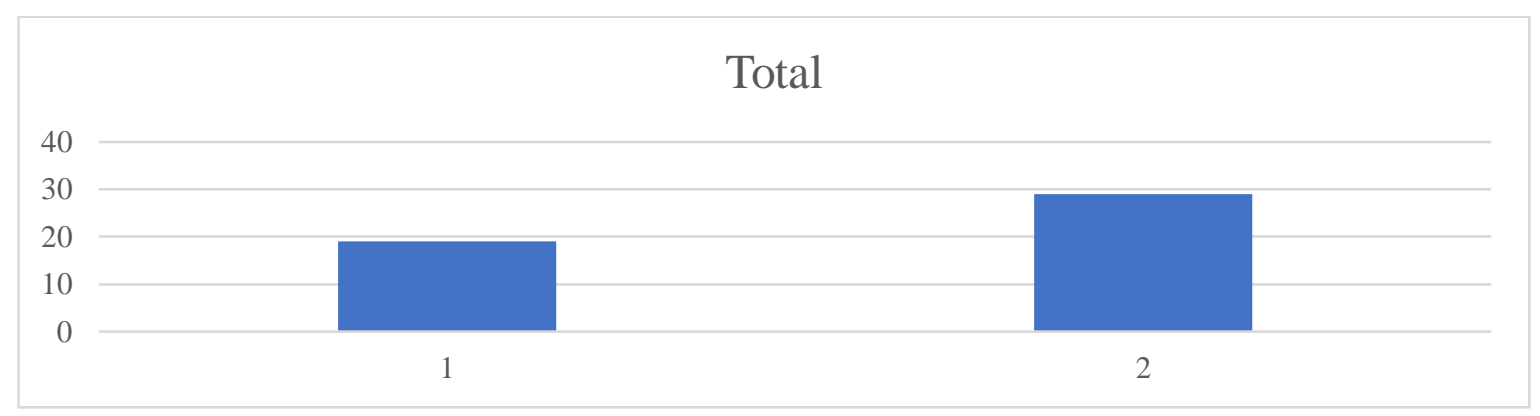

Gambar 11. Skor Awal dan Akhir Subjek 10

Pada subjek 10 dapat dikatakan bahwa total skor pre-test yang subjek peroleh adalah sebanyak 19 dan pada post-test subjek mendapat total skor sebanyak 29. Maka dapat dikatakan bahwa subjek 10 mengalami peningkatan sebanyak 65\%.

\subsection{Subjek 11}

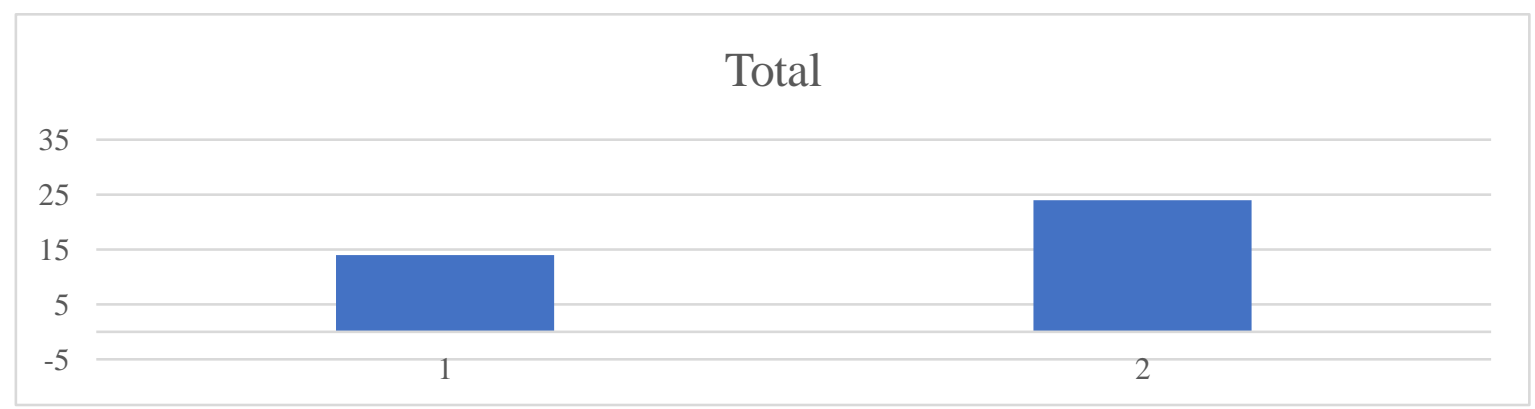

Gambar 12. Skor Awal dan Akhir Subjek 11

Pada data subjek 11, dapat dilihat bahwa pada total skor pre-test subjek mendapat total skor sebanyak 14 dan pada post-test subjek mendapat total skor sebanyak 24 . Sehingga dari pernyataan tersebut, dapat dikatakan bahwa subjek 11 mengalami peningkatan sebanyak $58 \%$. 


\subsection{Subjek 12}

\section{Total}

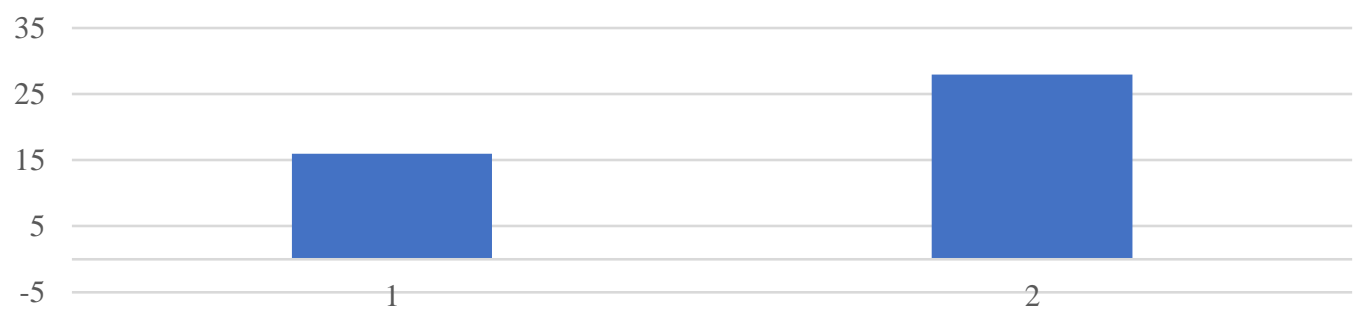

Gambar 13. Skor Awal dan Akhir Subjek 12

Pada subjek 12, dapat dilihat bahwa subjek mendapatkan total skor pada pre-test sebanyak 16 dan pada post-test subjek mendapat total skor sebanyak 28. Maka dapat dikatakan bahwa subjek 12 mengalami peningkatan sebanyak $57 \%$.

\subsection{Subjek 13}

\section{Total}

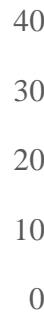

30

20

10

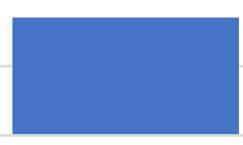

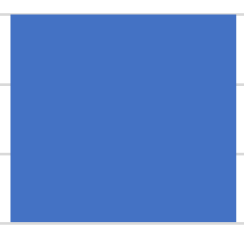

2

Gambar 14. Skor Awal dan Akhir Subjek 14

Pada data subjek 13 ia mendapatkan total skor sebanyak 17 pada pre-test dan pada posttest subjek mendapat total skor sebanyak 30. Maka dapat dikatakan bahwa subjek 13 mengalami peningkatan sebanyak $56 \%$.

\subsection{Subjek 14}

\section{Total}

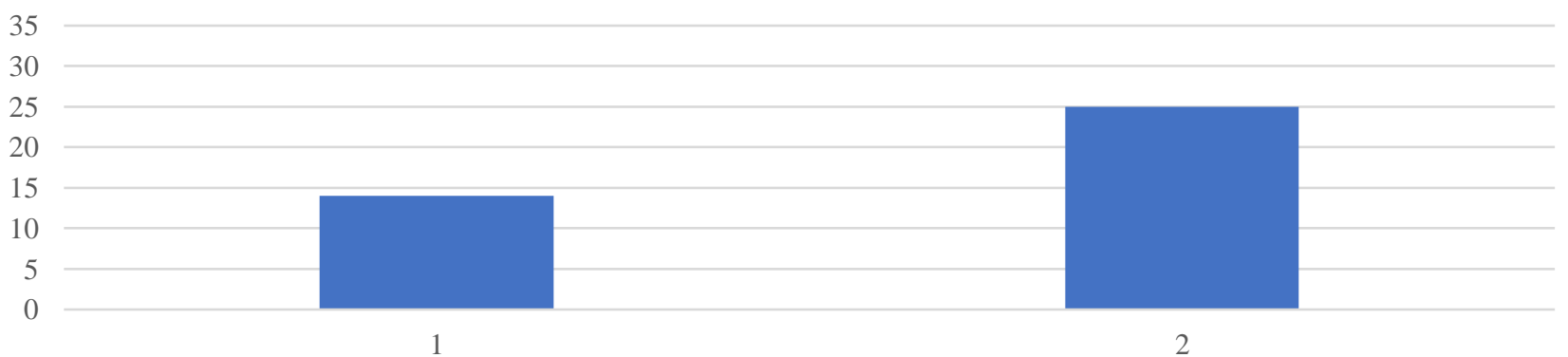

Gambar 15. Skor Awal dan Akhir Subjek 14

Pada subjek 14, dapat dilihat dari grafik diatas bahwa total skor pre-test dari subjek 14 adalah sebanyak 14 sedangkan untuk total skor post-test subjek mendapatkan skor 25. Maka dapat dikatakan bahwa subjek 14 mengalami peningkatan sebanyak 56\% dari pre- 
test dan post-testnya.

\subsection{Subjek 15}

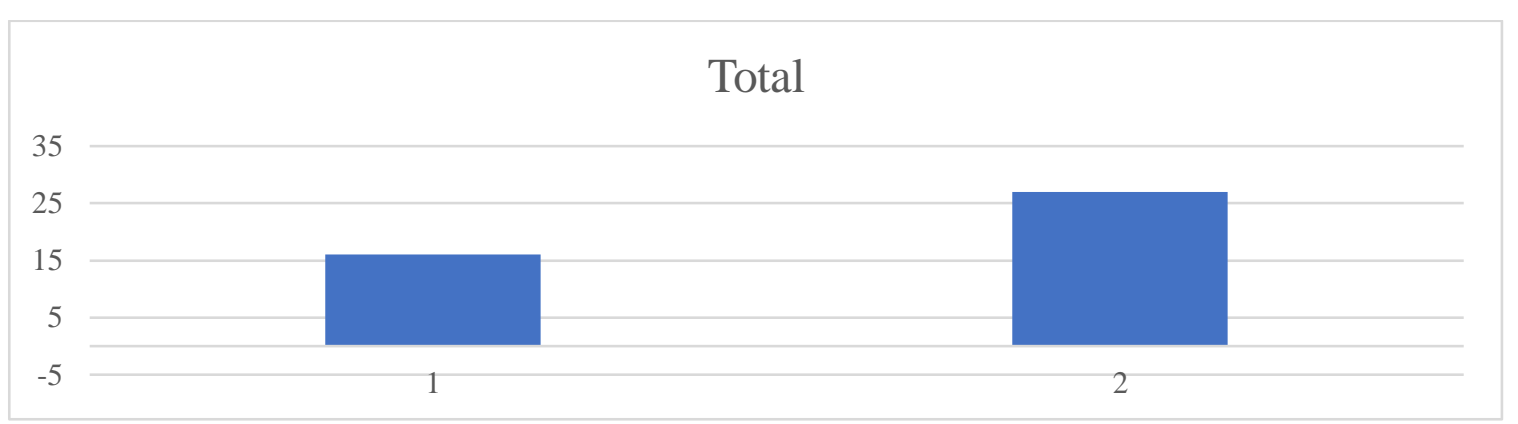

Gambar 16. Skor Awal dan Akhir Subjek 15

Pada data subjek 15, dapat dilihat bahwa subjek memiliki total skor pre-test sebanyak 16 , dan total skor post-test sebanyak 27. Dapat dikatakan bahwa subjek 15 mengalami peningkatan dari skor pre-test ke post-test sebanyak 59\%

\subsection{Subjek 16}

\section{Total}

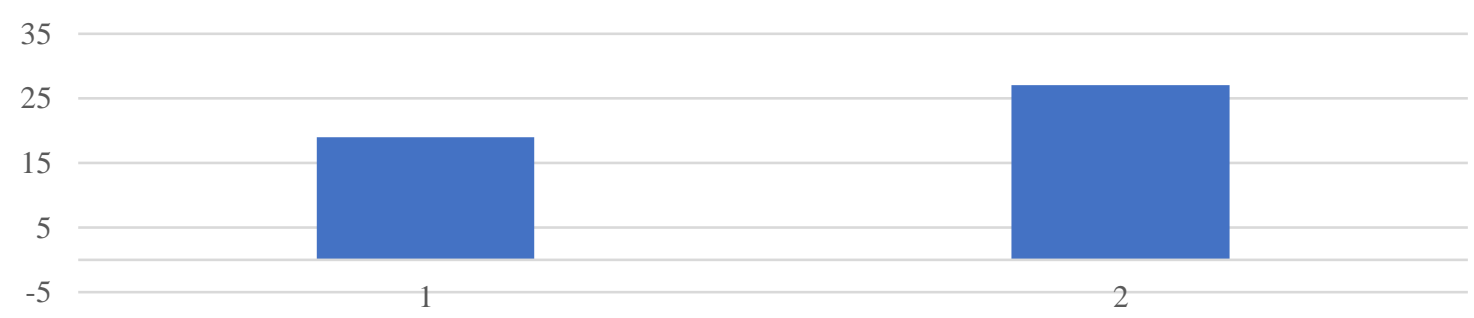

Gambar 17. Skor Awal dan Akhir Subjek 16

Pada data subjek 16, dapat dilihat dari grafik diatas bahwa ada peningkatan dari total skor pre-test dengan post-test sebanyak $70 \%$ dengan total skor pre-test sebanyak 19 dan total skor post-test sebanyak 27.

\subsection{Subjek 17}

\section{Total}

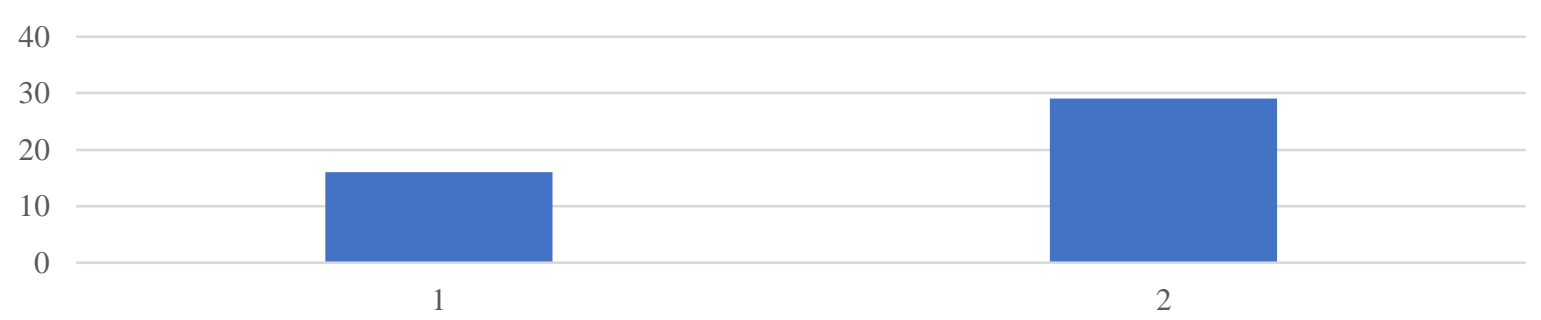

Gambar 18. Skor Awal dan Akhir Subjek 17

Pada data subjek 17, dapat dilihat bahwa subjek mendapatkan total skor pre-test dengan jumlah 16 dan total skor post-test dengan jumlah 29. Maka dari itu dapat dikatakan bahwa 
subjek mengalami peningkatan dari skor pre-test dan post-test sebanyak 55\%.

\subsection{Subjek 18}

\section{Total}

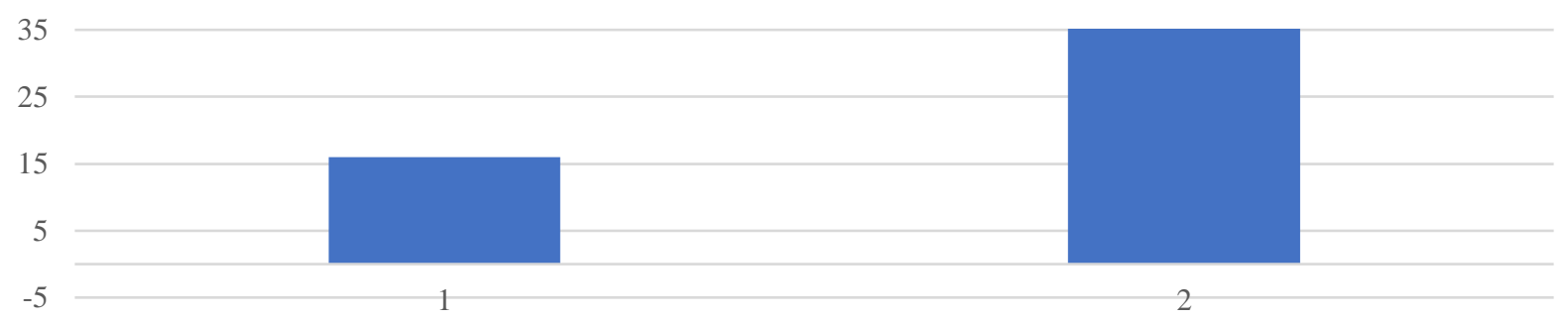

Gambar 19. Skor Awal dan Akhir Subjek 18

Pada data grafik subjek 18 dapat dilihat bahwa subjek mendapat total skor pada pre-test sebanyak 16 dan pada total skor post-test yaitu 36. Dari hasil tersebut maka dapat dikatakan bahwa subjek mengalami peningkatan skor yaitu sebanyak 44\% dari pre-test dan post-test.

\subsection{Subjek 19}

\section{Total}

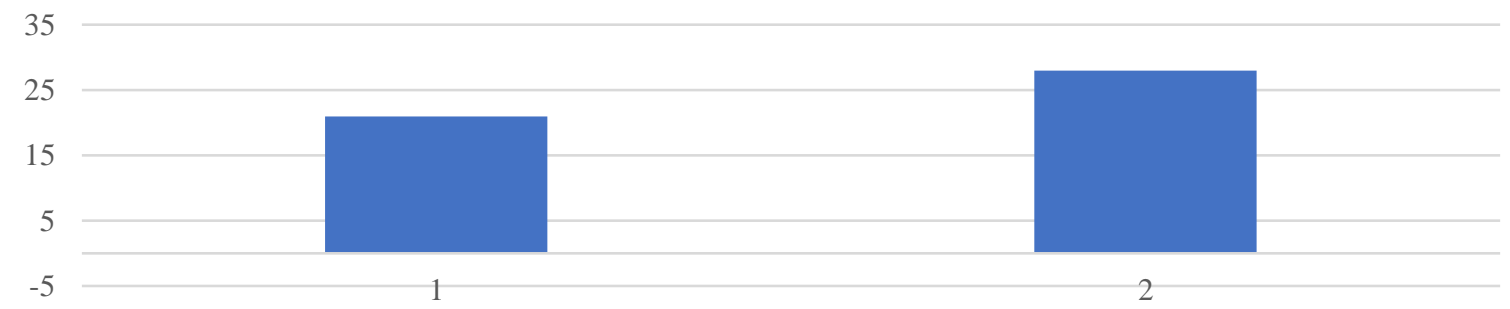

Gambar 20. Skor Awal dan Akhir Subjek 19

Pada subjek 19 dapat dilihat bahwa subjek mendapatkan total skor pre-test sebanyak 21 dan pada total skor post-test subjek mendapat skor sejumlah 28. Dari data tersebut, dapat dikatakan bahwa subjek 19 mengalami peningkatan dari pre-test dan post-test sebanyak $75 \%$.

\subsection{Subjek 20}

\section{Total}

40
30
20
10
0

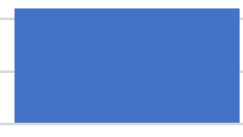

1

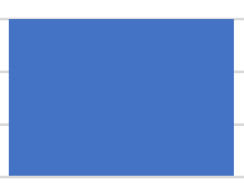

2

Gambar 21. Skor Awal dan Akhir Subjek 20 
Pada data subjek 20 dapat dilihat bahwa subjek mendapatkan total skor pre-test sebanyak 22 dan total skor post-test sebanyak 30. Dari data tersebut maka dapat dikatakan bahwa subjek mengalami peningkatan dari pre-test dan post-test sebanyak $73 \%$.

\subsection{Subjek 21}

\section{Total}

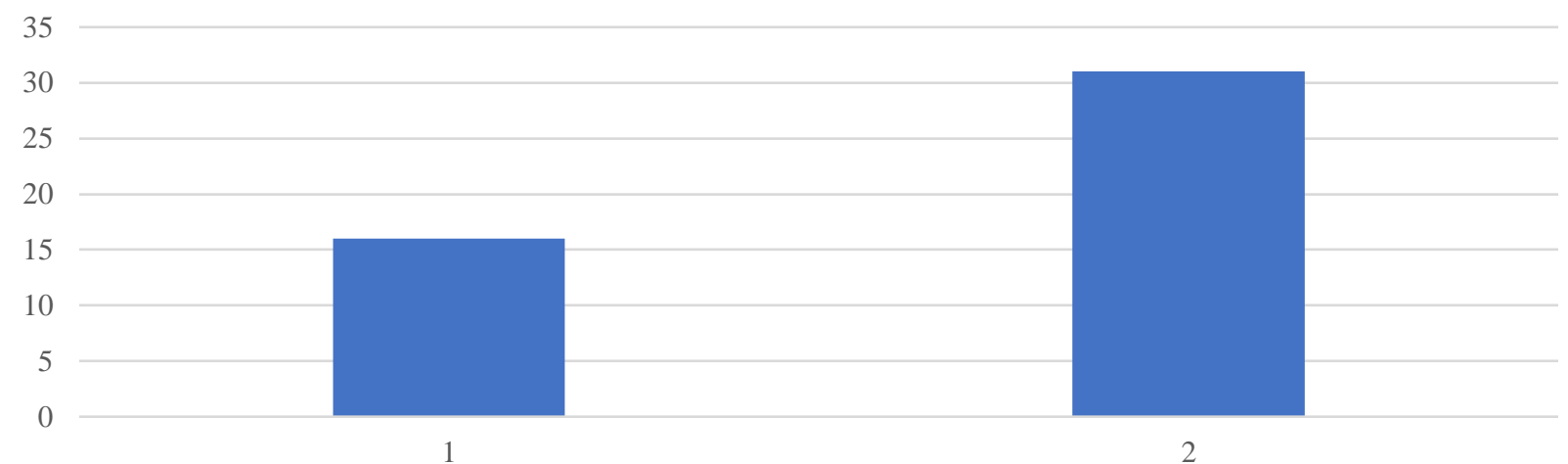

Gambar 22. Skor Awal dan Akhir Subjek 21

Pada data grafik dari subjek 21 dapat dilihat bahwa total skor dari pre-test subjek adalah sejumlah 16 dan pada total skor post-test subjek mendapatkan skor sebanyak 31 . Maka dari penjelasan diatas dapat dikatakan bahwa subjek mengalami peningkatan sebanyak $51 \%$.

\subsection{Subjek 22}

\section{Total}

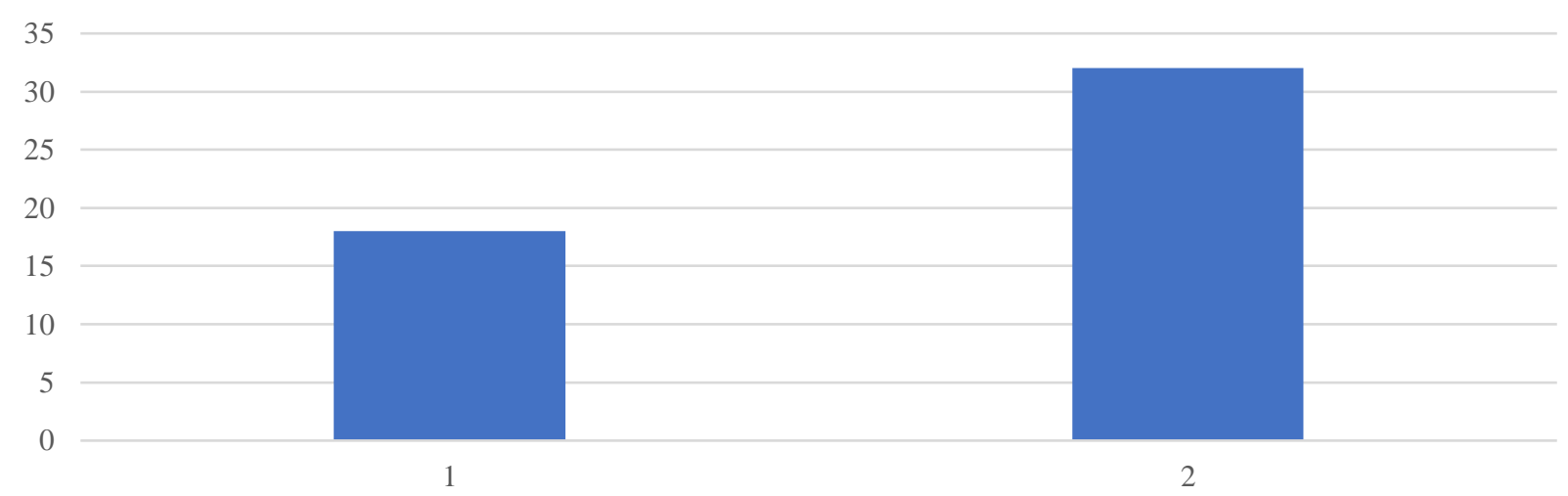

Gambar 23. Skor Awal dan Akhir Subjek 22

Dari data subjek 22 dapat dilihat bahwa subjek mendapatkan total skor pre-test sebanyak 18 dan total skor post-test sebanyak 32. Dari data tersebut maka dapat disimpulkan bahwa subjek 22 mengalami peningkatan dari total skor pre-test dan post-test sebanyak $56 \%$. 


\subsection{Subjek 23}

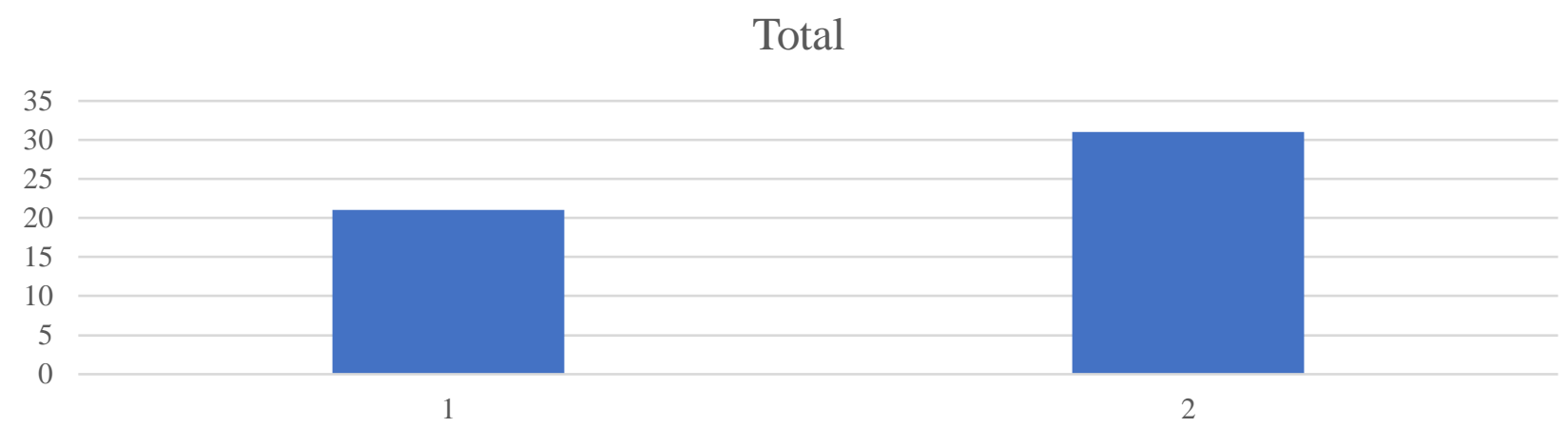

Gambar 24. Skor Awal dan Akhir Subjek 23

Pada subjek 23 dapat dilihat bahwa subjek mendapatkan total skor pre-test sebanyak 21 dan total skor post-test sebanyak 31 yang artinya subjek mengalami peningkatan dari pretest dan post-test sebanyak $67 \%$.

\subsection{Subjek 24}

\section{Total}

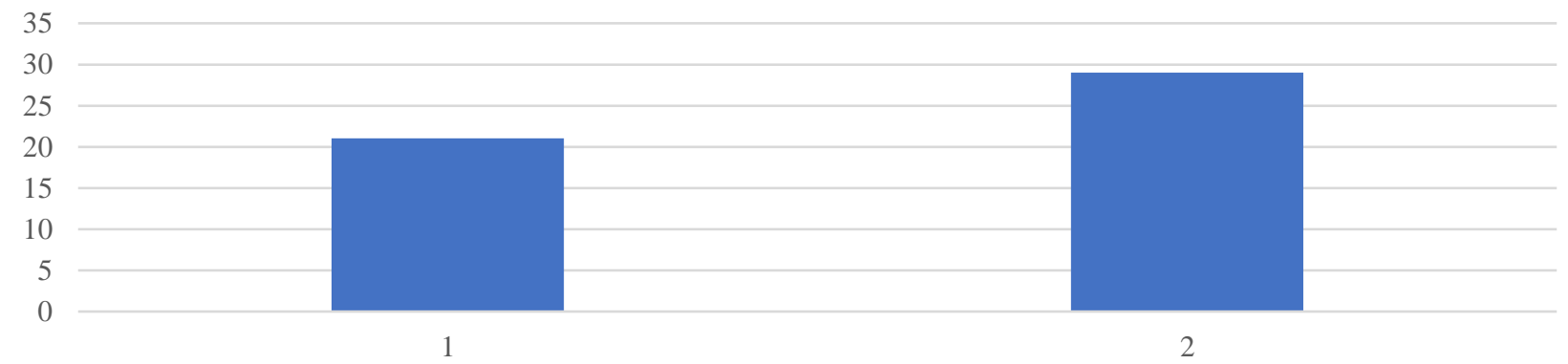

Gambar 25. Skor Awal dan Akhir Subjek 24

Pada data subjek 24, dapat dilihat bahwa subjek mendapatkan total skor pre-test sebanyak 21 dan total skor post-test sebanyak 29. Dari data tersebut maka dapat dikatakan bahwa subjek mengalami peningkatan sebanyak $72 \%$ dari hasil pre-test dan post-test nya.

\subsection{Subjek 25}

\section{Total}

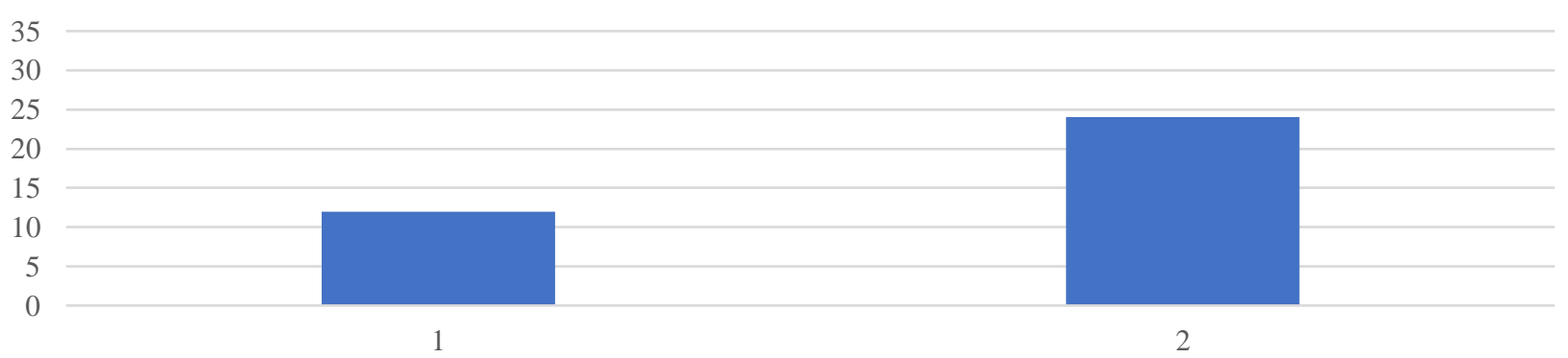

Gambar 26. Skor Awal dan Akhir Subjek 25 
Pada data subjek 25 dapat dilihat bahwa pada pre-test subjek mendapatkan total skor sebanyak 12 dan pada post-test subjek mendapat total skor sebanyak 24. Dari data tersebut dapat dikatakan bahwa subjek mengalami peningkatan dari pre-test ke post-test sebanyak $50 \%$.

\subsection{Subjek 26}

\section{Total}

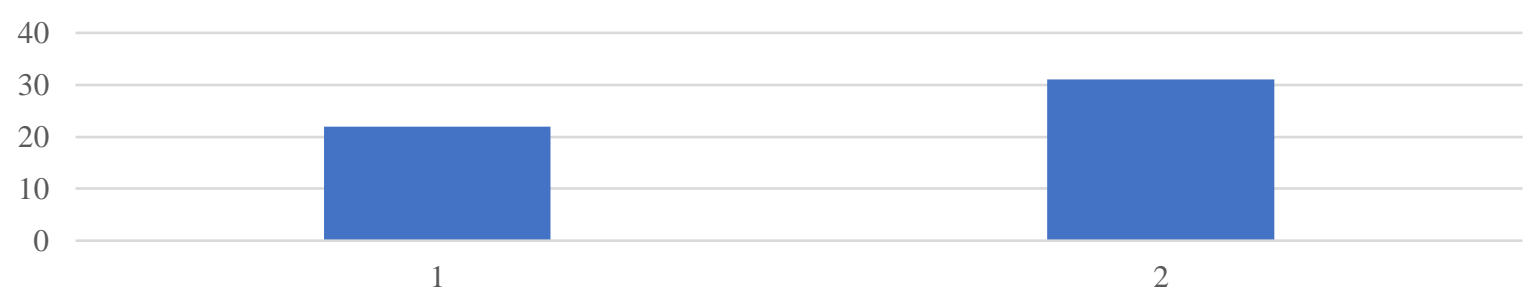

Gambar 27. Skor Awal dan Akhir Subjek 26

Pada data jumlah total skor pre-test dan post-test subjek 26 diatas, dapat dilihat bahwa subjek mendapatkan total skor pre-test sebanyak 22 dan pada total skor post-test subjek mendapatkan total skor sebanyak 31. Maka dari keterangan diatas, dapat dikatakan bahwa subjek mengalami peningkatan dari pre-test dan post-testna sebanyak $70 \%$.

\subsection{Subjek 27}

\section{Total}

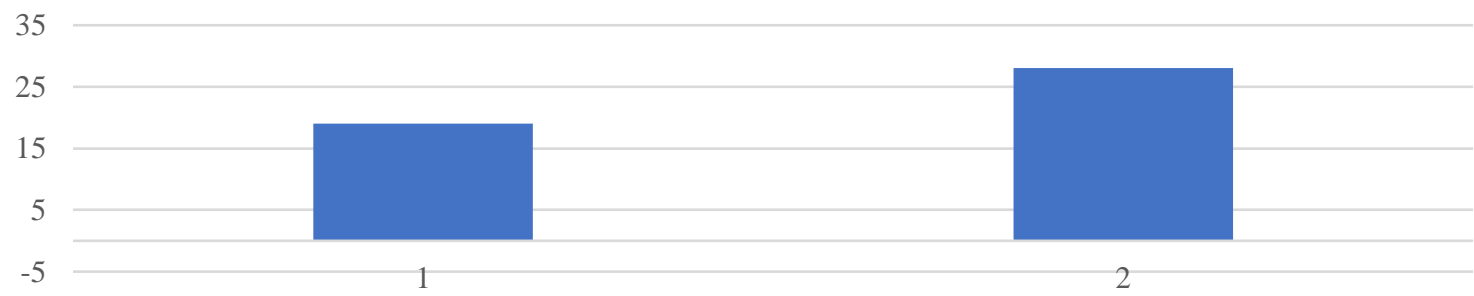

Gambar 28. Skor Awal dan Akhir Subjek 27

Pada data grafik subjek 27 diatas, dapat dilihat bahwa subjek mendapatkan total skor pretest sebanyak 19 dan total skor post-test sebanyak 28. Dari data tersebut dapat dikatakan bahwa subjek mengalami peningkatan dari pre-test dan post-test sebanyak $67 \%$.

\subsection{Subjek 28}

\section{Total}

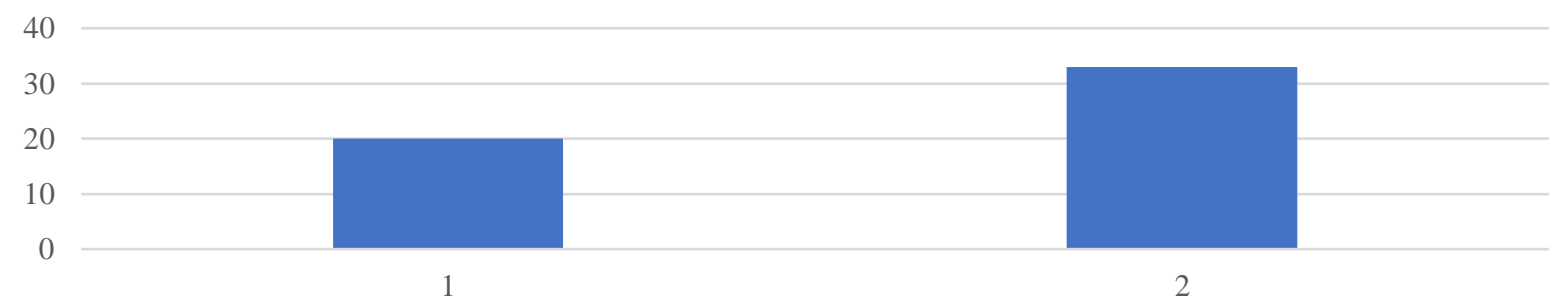

Gambar 29. Skor Awal dan Akhir Subjek 28 
Pada data subjek 28, dapat dikatakan bahwa subjek mendapatkan total skor pre-test sebanyak 20 dan total skor post-test sebanyak 33. Maka dari data tersebut dapat dikatakan bahwa subjek mengalami peningkatan skor sebanyak $60 \%$.

\subsection{Subjek 29}

\section{Total}

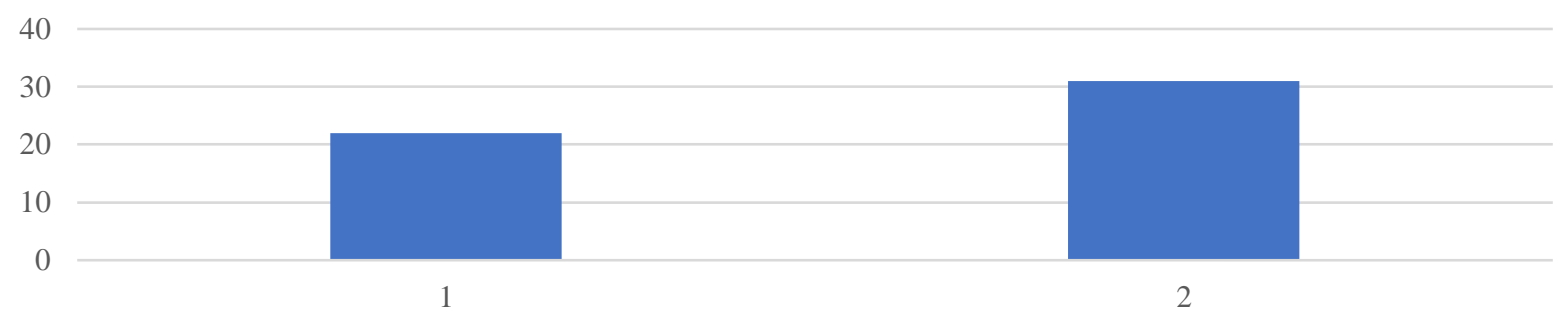

Gambar 30. Skor Awal dan Akhir Subjek 29

Pada data subjek 29, dapat dilihat dari grafik diatas bahwa subjek mendapatkan total skor pre-test sebanyak 22, dan pada total skor post-test subjek mendapatkan total sebanyak 31. Dari penjelasan diatas maka dapat dikatakan bahwa subjek mengalami peningkatan dari pre-test dan post test sebanyak $70 \%$.

\subsection{Subjek 30}

\section{Total}

35

25

15

5

$-5$
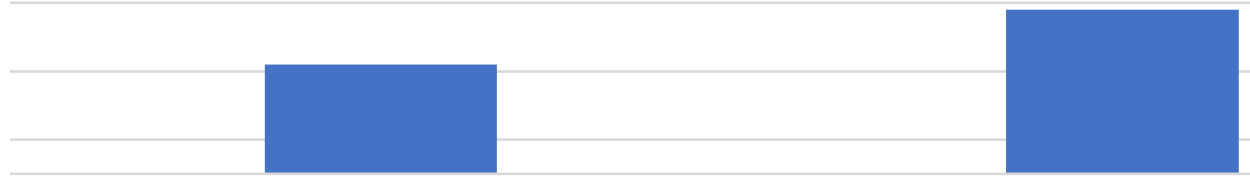

1

Gambar 31. Skor Awal dan Akhir Subjek 30

Pada data grafik subjek 30, dapat dilihat bahwa subjek mendapatkan total skor pre-test sebanyak 16 dan total skor post-test sebanyak 24. Dari data tersebut, dapat dikatakan bahwa subjek mengalami peningkatan dari pre-test dan post-testnya sebanyak $66 \%$.

\subsection{Subjek 31}

\section{Total}

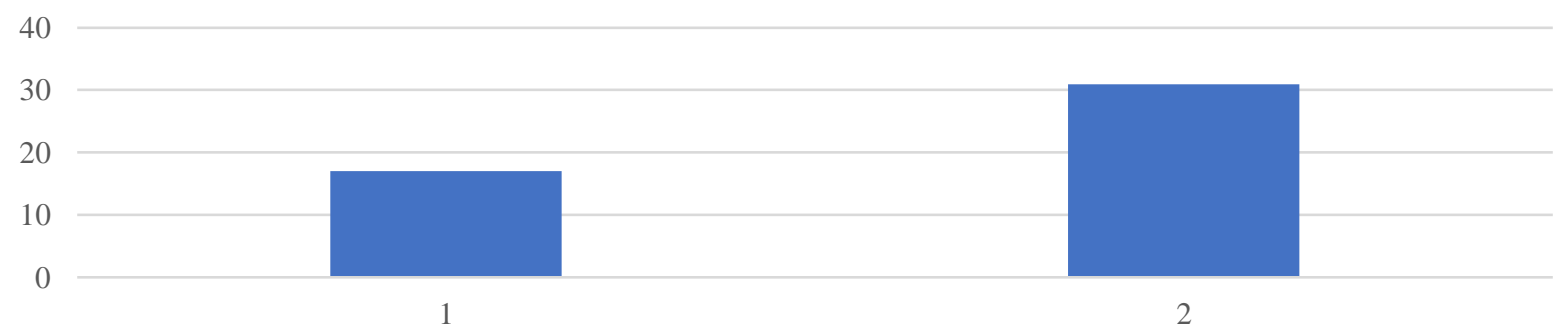

Gambar 32. Skor Awal dan Akhir Subjek 31 
Pada data dari subjek 31, dapat dilihat bahwa subjek mendapatkan total skor pre-test sebanyak 17 dan total skor post-test sebanyak 31. Dari data tersebut dapat dilihat bahwa subjek mengalami peningkatan dari pre-test dan post-testnya. Peningkatan yang didapatkan oleh subjek 31 adalah sebanyak $54 \%$.

\subsection{Subjek 32}

\section{Total}

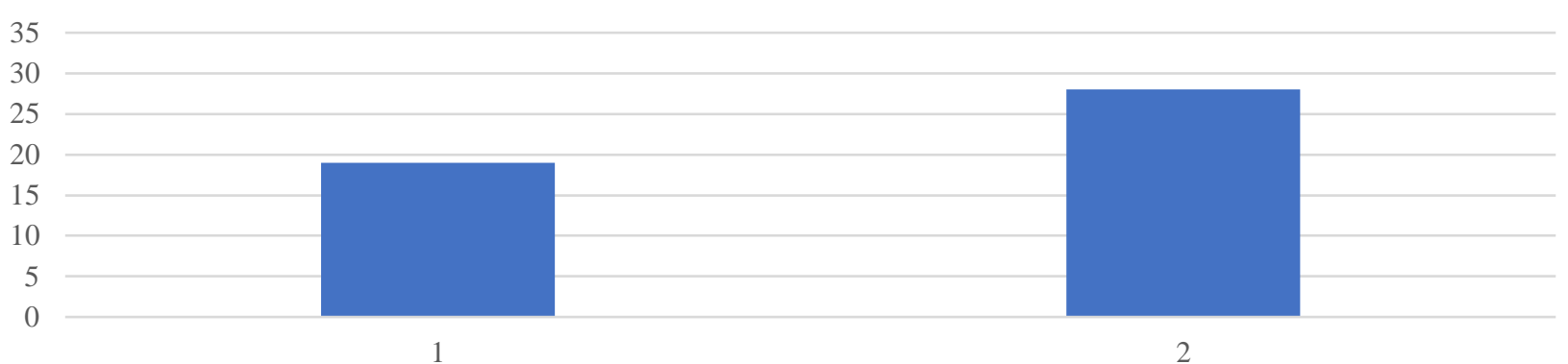

Gambar 33. Skor Awal dan Akhir Subjek 32

Pada data subjek 32, dapat dilihat bahwa subjek mendapatkan total skor pre-test sebanyak 19 dan total skor post-test sebanyak 28. Dari data tersebut maka dapat dikatakan bahwa subjek mengalami peningkatan dari pre-test dan post-testnya sebanyak $67 \%$.

\subsection{Subjek 33}

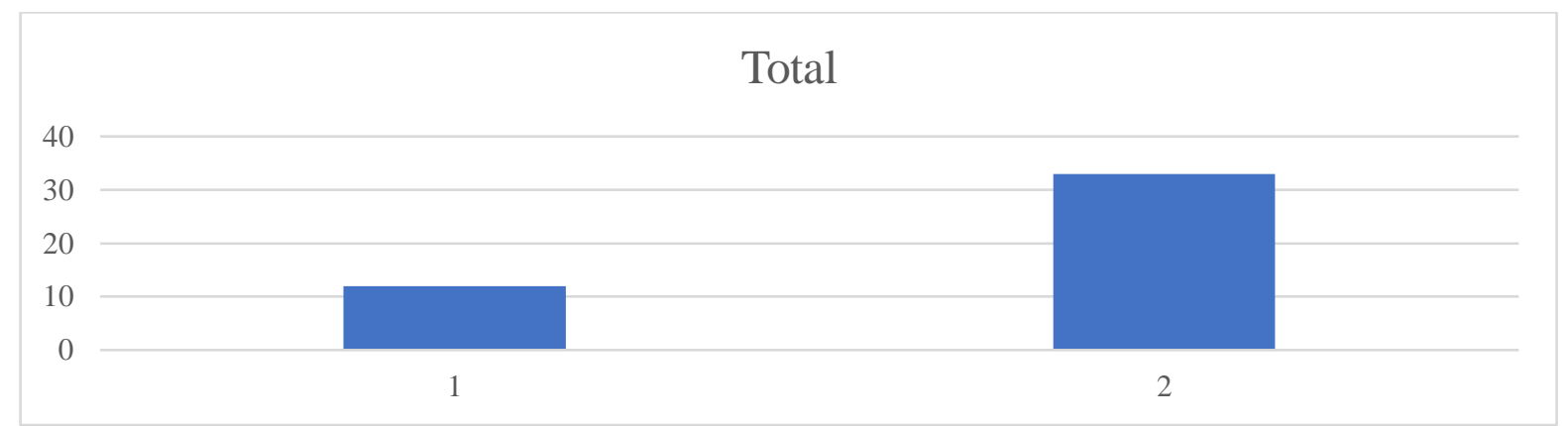

Gambar 34. Skor Awal dan Akhir Subjek 33

Pada data dari subjek 33 diatas, dapat dilihat bahwa subjek mendapatkan total skor pretest sebesar 12 dan total skor post-test sebesar 33. Dari data tersebut maka dapat dikatakan bahwa subjek mengalami peningkatan dari pre-test dan post-testnya yaitu sebanyak $36 \%$.

\subsection{Subjek 34}

\section{Total}

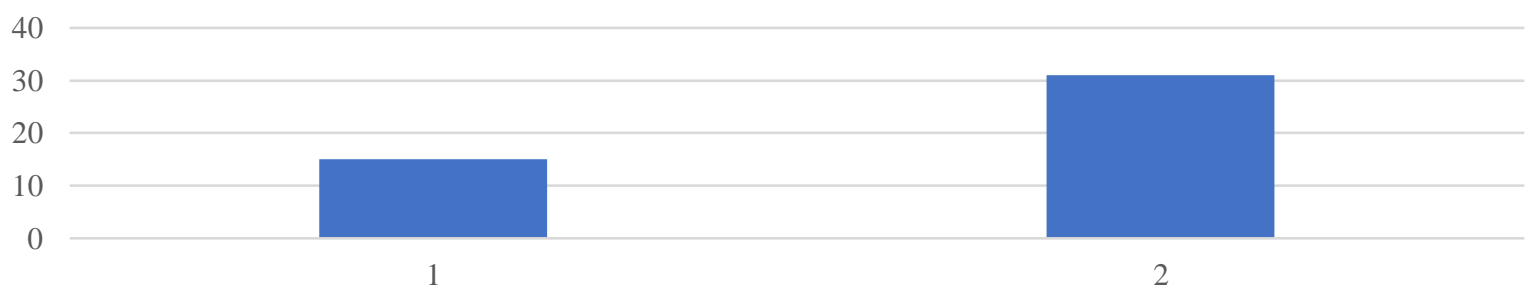

Gambar 35. Skor Awal dan Akhir Subjek 34 
Pada data grafik dari subjek 34, dapat dilihat bahwa subjek mendapatkan total skor pretest sebanyak 15 dan total skor post-test sebanyak 31. Maka dari data diatas dapat dikatakan bahwa subjek mengalami peningkatan sebanyak $48 \%$ dari pre-test dan post-test.

\subsection{Subjek 35}

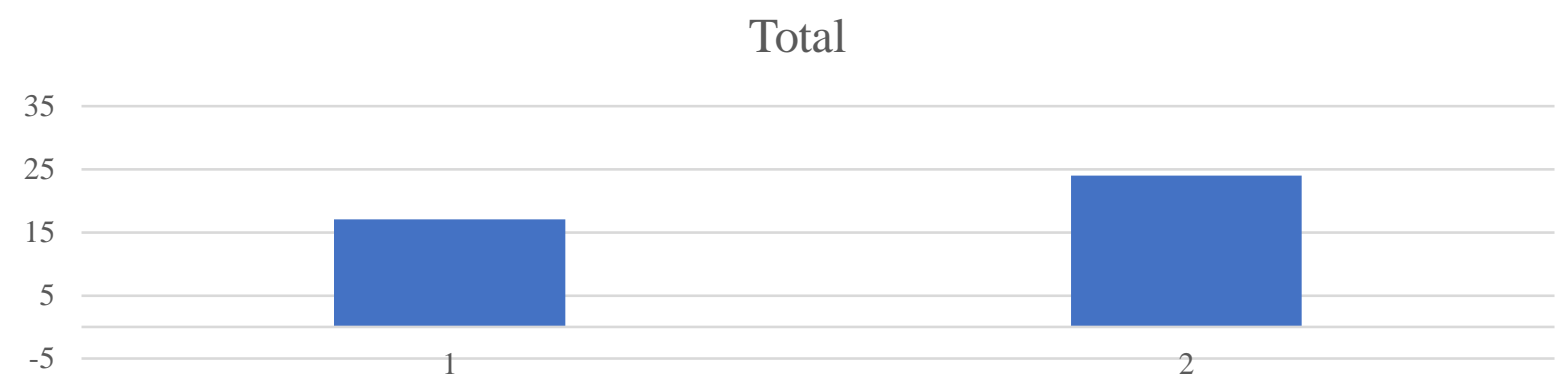

Gambar 36. Skor Awal dan Akhir Subjek 35

Pada data diatas, dapat dilihat bahwa subjek 35 mengalami kenaikan dari total skor pretest dan post-testnya dengan total skor pre-test sebesar 17 dan total post-test sebesar 24. Dari data tersebut peningkatan yangialami oleh subjek 35 adalah sebesar $48 \%$.

\subsection{Pembahasan}

Perubahan yang muncul dikarenakan perlakuan yang diberikan dipengaruhi oleh banyak faktor. Subjek dalam pengabdian ini adalah remaja dimana masa remaja adalah masaa membangun identitas diri bersama dengan kelompok. Masa remaja merupakan periode transisi yang ditandai dengan perubahan individu dalam segala aspek baik fisik, sosial, psikologi, dan mental. Selama periode ini, kebutuhan remaja untuk mengekspresikan diri dan bersosialisasi dengan teman-teman sebayanya berkembang pesat. Tahap perkembangan remaja merupakan masa yang penuh krisis, karena pada masa ini pada umumnya remaja mengalami kesulitan dalam usahanya menyelesaikan masalah yang dihadapinya, karena belum berpengalaman menghadapi hidup.

Support group therapy yang diberikan membuat informan mengenali dirinya, memahami bahwa setiap orang memiliki kelebihan dan kekurangan dan juga sejarah masing-masing, serta bisa menerima dirinya [6], Hal ini erat kaitannya dengan apa yang disampaikan oleh Erikson (dalam (Dahlan, 2009)) mengatakan bahwa "remaja berkaitan erat dengan perkembangan sense of identity vs role confusion", yaitu perasaan atau kesadaran dirinya [7].

Menurut (Doctherman et al., 2008) menyatakan bahwa salah satu jenis psikoterapi yang dapat digunakan untuk mengatasi kecemasan terutama permasalahan emosional serta memfasilitasi remaja untuk saling mengenal dan mempergunakan support system yang dapat di jangkau adalah terapi support group. Karena support group therapy adalah suatu proses terapi pada suatu kelompok yang memiliki permasalahan yang sama untuk mengkondisikan dan memberikan penguatan kepada kelompok maupun tiap anggota kelompok sesuai dengan permasalahan yang dialami [8].

Menurut Nilai \& Annatagia (2019), menyatakan bahwa terapi support group sangat baik dilakukan pada remaja, dimana para subjek saling memberikan dukungan dan feedback antar anggota kelompok [9]. Selain itu terjalin hubungan yang saling mendukung, yang secara tidak langsung menjadi pengua bagi remaja, karena mereka merasa tidak sendirian 
menghadapi permasalahan yang serupa.

Menurut penelitian yang dilakukan oleh Pangma,Tayraukham dan Nuangchalerm, Motivasi dengan dukungan (support) dapat diberikan melalui interaksi dengan kelompok sebaya (peer group) yang sesuai dengan salah satu ciri-ciri remaja adalah senang berinteraksi dengan kelompok sebaya. Didukung juga oleh Hoag dan Burlingame (Swasti et al., 2013) yang menyatakan bahwa jenis terapi yang paling efektif untuk dilakukan di lingkungan sekolah yakni terapi kelompok [10]. Terapi kelompok yang dapat dilakukan di sekolah salah satunya yakni peer support group therapy.

Peer support group sebagai dukungan sosial emosional, dukungan instrumental, dan saling berbagi dalam kondisi apapun untuk membawa perubahan sosial atau pribadi yang diinginkan [11]. Salmivalli mengemukakan peer support adalah kegiatan dimana terdapat dukungan dari teman sebaya yang dibangun dengan alasan teman-teman secara spontan membantu satu sama lain.

Peer support grouptherapy memungkinkan terjadi interaksi dan dinamika dalam kelompok yang diharapkan membantu untuk lebih terbuka. Support therapy ini dilakukan dengan menggunakan tiga pendekatan dasar: ekspresi perasaan, dukungan sosial, dan keterampilan kognitif. Menurut Spiegel (dalam Swasti., Helena., Pujasari, 2013) melalui kebebasan mengekspresikan perasaan, seseorang menjadi lebih terbuka mempelajari keterampilan koping yang baru. Hal ini akan meningkatkan kemampuan seseorang beradaptasi terhadap situasi kehidupan, membangun kekuatan ego, dan mengajarkan keterampilan penyelesaian masalah [10].

Melalui peer support group therapy, remaja merasakan adanya kesamaan satu dengan lainnya seperti di bidang usia, kebutuhan dan tujuan yang dapat memperkuat diri dan remaja memiliki kecenderungan untuk lebih mudah menerima informasi dan mengikuti masukan yang diberikan oleh teman seusianya [10]. (Wolfert, 2004) menjelaskan bahwa manusia yang sehat memiliki kebutuhan untuk memperoleh dukungan dari teman-teman atau orang lain [12]. Dukungan sosial adalah faktor psikososial yang mempengaruhi tingkat resiliensi individu.

\section{Kesimpulan}

1. Support group therapy yang diberikan membuat informan mengenali dirinya, memahami bahwa setiap orang memiliki kelebihan dan kekurangan dan juga sejarah masing-masing, serta bisa menerima dirinya

2. Support group therapy yang telah dilaksanakan mampu memberikan fungsi terapeutiknya terhadap kelompok, yaitu sebagai faktor dukungan (supportive factors), faktor keterbukaan diri dan katarsis, faktor belajar kebijaksanaan atau kearifan dari anggota kelompok lainnya, serta faktor-faktor psikologis yang berkaitan dengan bagaimana menjalin hubungan dengan orang lain dan bagaimana memahami diri sendiri

\section{Daftar Pustaka}

[1] Sarwono, S. W. (2011). Psikologi Remaja. Raja Grafindo Persada.

[2] Djohan. (2006). Terapi musik: teori dan aplikasi. Yogyakarta: Galangpress.

[3] Sakalasastra, P. P., \& Herdiana, E. (2012). Dampak Psikososial Pada Anak Jalanan Korban Pelecehan 
Seksual Yang Tinggal di Liponsos Anak Surabaya. Jurnal Psikologi Kepribadian Dan Sosial, Universitas Airlangga Surabaya, I (2).

[4] Suardiman, S. P. (2011). Psikologi Usia Lanjut. Gajah Mada University press.

[5] Huda, M. (2009). Pekerjaan Sosial dan Kesejahteraan Sosial Sebuah Pengantar. Yogyakarta: Pustaka Pelajar.

[6] Salamah, U. (2015). Communication dan Support Group Therapy" dalam Mengembangkan Potensi Resiliensi Remaja Dari Keluarga Single Parents. Jurnal Komunikasi Fakultas IImu Komunikasi Universitas Garut, 1(1), 2461-0836.

[7] Dahlan, D. (2009). Psikologi Perkembangan Anak. Bandung: Remaja Rosdakarya.

[8] Doctherman, J. M., Bulecheck, G., \& Butcher, H. (2008). Nursing Interventions Classifications (NIC (5th editio). Mosby Elseiver.

[9] Nilai, P., \& Annatagia, L. (2019). Support Group Therapy untuk Menurunkan Kecemasan Pada Siswa yang Mengalami Bullying. Jurnal Psikologi Klinis Indonesia, 4(1).

[10] Swasti, K. G., Helena, N., \& Pujasari, H. (2013). Penurunan Ansietas Dalam Menghadapi Ujian Nasional Pada Siswa Kelas XII SMAN X Melalui Pemberian Terapi Suportif. Jurnal Keperawatan Soedirman, 8(3), 127-142. https://doi.org/http://dx.doi.org/10.20884/1.jks.2013.8.2.479

[11] Ekasari, A., \& Andriyani, Z. (2013). Pengaruh Peer Group Support dan Self-Esteem Terhadap Resilience Pada Siswa SMAN Tambun Utara Bekasi. Jurnal Soul, 6(1).

[12] Wolfert, A. D. (2004). The Understanding Your Grief Support Group Guide: Starting and Leading a Bereavement Support Group. Companion Press. 